\title{
BASTA CRER EM JESUS CRISTO PARA SER SALVO?
}

\section{ARTIGO ORIGINAL}

NASCIMENTO, Marcelo Victor Rodrigues do ${ }^{1}$

NASCIMENTO, Marcelo Victor Rodrigues do. Basta crer em Jesus cristo para ser salvo? Revista Científica Multidisciplinar Núcleo do Conhecimento. Ano. 06, Ed. 12, Vol. 12, pp. 127-149. Dezembro de 2021. ISSN: 2448-0959, Link de acesso: https://www.nucleodoconhecimento.com.br/teologia/basta-crer,

DOI: 10.32749/nucleodoconhecimento.com.br/teologia/basta-crer

\section{RESUMO}

O Evangelho de Jesus Cristo, segundo Marcos, diz, em Marcos 16:16, que quem crer e for batizado será salvo, sugerindo duas etapas para a salvação: a fé e a ação. Contudo, trata-se de um assunto polêmico, pois no verso seguinte é dito que quem não crer será condenado, sem citar o batismo. Assim sendo, o presente artigo, tem como questão norteadora: como compreender as palavras de Jesus quando disse: "Quem crer e for batizado será salvo" (Marcos 16:16), sugerindo duas etapas para a salvação: a fé e a ação? Portanto, tem como objetivo investigar, com base em Marcos 16:16, se há necessidade de produzir as obras da fé, começando pelo batismo, para que o cristão seja salvo, ou basta apenas crer em Jesus Cristo, o Filho de Deus, sem necessidade de produzir qualquer obra. Metodologicamente, foi realizada uma análise qualitativa de 15 (quinze) matérias postadas na internet por teólogos e estudiosos da Bíblia, cujo tema era, direta ou indiretamente, a soteriologia cristã, aliada a um estudo descritivo e transversal, destinado a observar o número de

\footnotetext{
${ }^{1}$ Doutor e Mestre em Teologia, pela Universidade da Bíblia - São Paulo. Mestrando em Treino Desportivo, pela Escola Superior de Desporto e Lazer - Melgaço, Portugal. Pós-graduado em Ciências da Religião, pelo Instituto Aliança de Linguística, Teologia e Humanidades (IALTH) - Recife - PE. Pós-graduado em Magistério do Ensino Superior - Universidade Paulista - SP. Pós-graduado em Fisiologia do Exercício - Escola Paulista de Medicina SP. Pós-graduado em Exercícios Resistidos na Saúde, na Doença e no Envelhecimento - Faculdade de Medicina da USP. Licenciado em Educação Física, pela Escola de Educação Física do Exército (EsEFEx) - Rio de Janeiro. Bacharel em Ciências Militares, pela Academia da Força Aérea Brasileira (AFA) - Pirassununga - SP. Bacharel em Administração de Empresas, pela Universidade Presbiteriana Mackenzie - São Paulo. Acadêmico do Curso de Licenciatura em Filosofia, pelo Instituto Aliança de Linguística, Teologia e Humanidades (IALTH) - Recife - PE.
}

$\mathrm{RC}: 104461$

Disponível em: https://www.nucleodoconhecimento.com.br/teologia/basta-crer 
interlocutores que defendiam esta ou aquela corrente soteriológica, ambos realizados no período de setembro a outubro de 2021. Como resultados, verificou-se que $53 \%$ dos interlocutores selecionadas disseram crer que o batismo tem implicações salvíficas, tomando por base algumas passagens bíblicas, e 47\% disseram crer que não, desconsiderando a regra da língua portuguesa relativa à conjunção aditiva, que indica a soma de dois elementos, e a teoria dos conjuntos, que mostra que onde há dois elementos há um. Por fim, com base nos depoimentos, é possível concluir que, embora a fé seja o fundamento do cristianismo, contudo, não basta crer para ser salvo, sendo necessário colocar-se à disposição do Espírito Santo para que, ajudado por Ele, o cristão possa, a partir do batismo, produzir os frutos dignos de arrependimento (obras de fé), sem os quais a fé é morta.

Palavras-chave: soteriologia, salvação, perseverança dos santos, monergismo, sinergismo.

\section{INTRODUÇÃO}

Conforme nos mostra a história, a busca pelo sentido da vida, da existência e da morte conduziu o homem por diferentes caminhos, passando pela mitologia grega, pela crença nas forças da natureza, pelo cristianismo, pelo período medieval, pelo iluminismo e pelo advento da revolução científica do mundo moderno, cujas descobertas despiram as suntuosas "vestes sagradas" que a religião e a metafísica haviam vestido no universo, dando-lhe novas roupagens (LOTT, 2010, p. 96).

Embora bastante significativa, a transição da fé mitológica para o racionalismo grego parece não ter sido tão impactante quanto o surgimento do cristianismo no cenário mundial (GASTON, 2020; ROHREGGER, 2020). Jesus Cristo causou uma verdadeira revolução espiritual no mundo greco-romano, abalando todas as suas estruturas hegemônicas, por apresentar, à humanidade, uma resposta clara para a existência humana, bem como a solução para o problema da morte, na pessoa do "Deus que se fizera carne e teria habitado entre os mortais", trazendo salvação ao mundo: "E o Verbo (divino) se fez carne, e habitou entre nós, e vimos a sua glória, 
como a glória do unigênito do Pai, cheio de graça e de verdade" (João 1:14) (BÍBLIA ON-LINE, 2021; GASTON, 2020).

A soteriologia cristã (o estudo da salvação) terminou por introduzir conceitos religiosos revolucionários em um mundo dominado pela filosofia grega, tais como: o plano eterno de salvação; o estado do homem em relação ao pecado; a expiação dos pecados pelo sangue de Cristo; a graça divina e seu modus operandi; a obra do Espírito Santo; e o destino final do homem (PALÁCIO, 2010; SILVA, 2009).

A relevância de tal fato histórico foi tão marcante que a emancipação conquistada pelos filósofos gregos em relação à religião acabou por cair por terra e o cristianismo fez com que a religião conseguisse ultrapassar a filosofia, mantendo-a como serva ao longo de todo o período medieval (do Século V ao Século XV), tendo, inclusive, usado conceitos filosóficos para solidificar a fé cristã, como a metafísica de Platão (LOTT, 2010; CARVALHO, 2000).

Isso foi possível, em grande parte, porque o cristianismo alcançou as diversas classes sociais, especialmente as mais humildes, diferentemente das escolas filosóficas gregas que eram voltadas para um grupo restrito de privilegiados, os quais, por serem poucos (em comparação com o restante da população), acabaram por ser dominados por um sentimento de "orgulho filosófico" que os impediu de enxergar a sublimidade, a singularidade e a superioridade da Obra de Cristo (LOTT, 2010; PEIXOTO, 2017).

Segundo o teólogo e professor de soteriologia Marcelo Berti (BERTI, 2015), o significado da Obra de Cristo pode ser resumido em quatro ideias fundamentais, que giram em torno da crucificação na cruz do Calvário, quais sejam:

(1) A morte de Cristo foi propiciação pelo pecado de toda a humanidade, isto é, Sua morte é suficiente para perdoar a todos os seres humanos (Romanos 5:18) (BÍBLIA ON-LINE, 2021; SILVA, 2009); 
(2) A morte de Cristo substituiu a morte de todos os pecadores, isto é, Ele tomou o lugar dos pecadores, assumindo sobre si as suas culpas por graça (2 Coríntios 5:1415) (BÍBLIA ON-LINE, 2021; SILVA, 2009);

(3) A morte de Cristo trouxe redenção para os pecados, isto é, Ele pagou o preço pelo resgate com o seu próprio sangue (1 Coríntios 6:20; Atos 20:28; Apocalipse 5:9) (BÍBLIA ON-LINE, 2021; SILVA, 2009); e

(4) A morte de Cristo reconciliou o homem com Deus, isto é, Sua morte desfez a inimizade que havia entre ambos (2 Coríntios 5:19; Romanos 5:10; Colossenses 1:21) (BÍBLIA ON-LINE, 2021; SILVA, 2009).

No tocante às consequências da Obra de Cristo, o referido teólogo aponta para os seguintes resultados, explicitados nas Escrituras Sagradas (BERTI, 2015):

(1) Justificação: os cristãos são declarados justos diante de Deus (Romanos 4:25) (BÍBLIA ON-LINE, 2021);

(2) Adoção: os cristãos são adotados como filhos de Deus e herdeiros das Suas gloriosas promessas (João 1;12; Romanos 8:15) (BÍBLIA ON-LINE, 2021);

(3) Regeneração: os cristãos têm suas naturezas morais transformadas pelo poder do Espírito Santo (2 Coríntios 5:17) (BíBLIA ON-LINE, 2021);

(4) Santificação: os cristãos passam a ser separados do mundo, para servirem a Deus em espírito e em verdade (Efésios 2:19; Hebreus 10:10) (BÍBLIA ON-LINE, 2021);

(5) Fim da Lei Mosaica: a Obra de Cristo trouxe o total cumprimento do Velho Testamento e a inauguração de um Novo Testamento (Romanos 10:4) (BíBLIA ONLINE, 2021); e

(6) Glorificação: os cristãos, como um espelho, pela presença do Espírito Santo, já refletem a glória do Senhor, contudo a plenitude dar-se-á por ocasião da volta de 
Cristo (2 Coríntios 3:18; Romanos 8:30; 1 Coríntios 15:52-54) (BÍBLIA ON-LINE, 2021).

Dentre as consequências supracitadas, a Bíblia Sagrada apresenta a santificação como algo formado por duas etapas: uma imediata, que ocorre no momento da conversão, e outra contínua, como um processo de busca constante por parte do cristão para alcançar uma qualidade moral semelhante à de Cristo (2 Coríntios 3:18; Romanos 8:29) (BÍBLIA ON-LINE, 2021; MELLO, 2020a).

Tal processo de santificação fundamenta-se sobre uma forte tensão, pois, ainda que a mesma seja reconhecidamente uma obra da graça divina, contudo, segundo a Bíblia, requer uma busca pessoal por parte do cristão, sendo algo relacional (RODRIGUES, 2017). A tensão está em dar ênfase de forma exagerada na ação divina, que leva à crença de que o sujeito é parte passiva nesse processo, e em dar ênfase exagerada na busca pessoal, que conduz à meritocracia e à ideia de salvação pelas obras (BERTI, 2015; MELLO, 2016b).

Esse suposto paradoxo é algo tão profundo que redundou no surgimento de três correntes soteriológicas distintas, as quais aplicam a ênfase na primeira ou na segunda proposta, quais sejam: (1) O Calvinismo, que enfatiza a ação divina (monergismo); (2) O Arminianismo, que enfatiza a busca pessoal (sinergismo); e (3) O Molinismo, que compatibiliza a ação divina e a busca pessoal (NASCIMENTO, 2020b; FURTADO e BEZERRA, 2017; MELLO, 2016b).

Para grande parte dos teólogos, a solução para tal impasse gira em torno do entendimento de que a santificação é algo transcendente, mas com a participação ativa do ser humano (KUNRATH, 2007). Aliás, a restrição imposta pela Bíblia para que a pessoa possa ver a Deus no último Dia passa pela necessidade de santificação, sem a qual ninguém $O$ verá (Hebreus 12:14), tornando, portanto, tal processo uma questão de vida ou morte eterna (KUNRATH, 2007; BíBLIA ON-LINE, 2021). 
Assim sendo, como consequência da necessidade da participação ativa do homem na santificação, resta saber se basta crer para ser salvo ou se a fé em Cristo deve estar acompanhada das obras (resultantes da fé) para que a salvação ocorra, aquilo que a Bíblia chama de frutos do espírito: "Mas o fruto do Espírito é: amor, gozo, paz, longanimidade, benignidade, bondade, fé, mansidão, temperança" (Gálatas 5:22) (BÍBLIA ON-LINE, 2021).

Nessa mesma linha, como compreender as palavras de Jesus quando disse: "Quem crer e for batizado será salvo" (Marcos 16:16), sugerindo duas etapas para a salvação: a fé e a ação?

Dessa forma, este artigo tem por objetivo investigar, com base em Marcos 16:16 (BÍBLIA ON-LINE, 2021), se há necessidade de produzir as obras da fé, começando pelo batismo, para que o cristão seja salvo, ou basta apenas crer em Jesus Cristo, o Filho de Deus, sem necessidade de qualquer obra.

\section{METODOLOGIA}

Foi utilizado nesta investigação o método qualitativo conhecido como método histórico, valendo-se de um levantamento bibliográfico e de depoimentos sobre determinado tema, a fim de permitir uma correta análise do contexto em que ele está imerso, com vistas a melhor entendê-lo (VIEIRA, 2010). Concomitantemente, foi realizado um estudo descritivo e transversal, destinado a observar o número de interlocutores que defendiam esta ou aquela corrente soteriológica (CERVO et al., 2007).

Os instrumentos de coleta de dados foram matérias, escritas e/ou faladas, publicadas, na rede mundial de computadores (internet), por teólogos e estudiosos da Bíblia, das diversas vertentes cristãs, sem privilegiar esta ou aquela denominação religiosa ou corrente doutrinária. Foram selecionadas, aleatoriamente, 15 (quinze) matérias, cujo o tema era soteriologia cristã, as quais abordavam, direta ou indiretamente, a passagem descrita em Marcos 16:16 (BÍBLIA ON-LINE, 2021). 
Foram introduzidas as expressões "soteriologia", "Marcos 16:16", "batismo salvífico", "perseverança dos santos", "sinergismo" e "monergismo" na ferramenta google, resultado em diversas matérias relacionadas ao tema em pauta, dentre as quais foram escolhidas 15 (quinze) delas.

\section{RESULTADOS}

As matérias selecionadas apresentaram as seguintes afirmações relacionadas ao tema por parte de seus interlocutores:

1ª Matéria: "Quem crê e for batizado, será salvo!" (BARROS, 2017).

O interlocutor defendeu a crença de que a justificação tem, como meios de graça, a fé e o batismo (minuto 1:02), citando, especialmente, as seguintes passagens:

- "Quem crer e for batizado será salvo; mas quem não crer será condenado" (Marcos 16:16) (BÍBLIA ON-LINE, 2021);

- "... na qual poucas (isto é, oito) almas se salvaram pela água; que também, como uma verdadeira figura, agora vos salva, o batismo..." (1 Pedro 3:19-21) (BÍBLIA ONLINE, 2021); e

- "... aquele que não nascer da água e do Espírito, não pode entrar no reino de Deus" (João 3:5) (BÍBLIA ON-LINE, 2021).

2ª Matéria: "O Batismo bíblico salva I Regeneração Batismal" (BRASILINO, 2018).

O interlocutor defendeu a crença na regeneração batismal (minuto 0:36), afirmando que o batismo é o momento em que se cumpre a promessa de remissão dos pecados, sem que Deus esteja preso a tal sacramento, pois, como no caso de Cornélio, Ele deu-Ihe o Espírito Santo, extraordinariamente, antes de ser batizado.

O interlocutor comparou o batismo à confissão de um determinado pecado que um cristão venha cometer, cujo perdão não ocorre no momento do arrependimento, mas, sim, quando ele o confessa diante de Deus (minuto 15:30). 
Como base para o seu raciocínio, o autor citou os seguintes versos bíblicos:

- "Um só Senhor, uma só fé, um só batismo" (Efésio 4:5) (BÍBLIA ON-LINE, 2021), anulando a ideia de que haja batismos distintos (nas águas, no espírito, na morte);

- "Arrependei-vos, e cada um de vós seja batizado em nome de Jesus Cristo, para perdão dos pecados; e recebereis o dom do Espírito Santo" (Atos 2:38) (BÍBLIA ONLINE, 2021), destacando a remissão dos pecados como obra do batismo;

- "E agora por que te deténs? Levanta-te, e batiza-te, e lava os teus pecados, invocando o nome do Senhor" (Atos 22:16), reafirmando a remissão batismal dos pecados (BÍBLIA ON-LINE, 2021);

- "De sorte que se fomos sepultados com ele pelo batismo (nas águas) na morte (de Cristo); para que, como Cristo foi ressuscitado dentre os mortos, pela glória do Pai, assim andemos nós também em novidade de vida" (Romanos 6:3-5), trazendo a ideia de uma união real com Cristo e não de uma simples confissão pública, ou apenas a identificação com Cristo, ou apenas um simbolismo (BÍBLIA ON-LINE, 2021);

- "... sepultados com ele no batismo, nele também ressuscitastes pela fé no poder de Deus, que o ressuscitou dentre os mortos. E, quando vós estáveis mortos nos pecados, e na incircuncisão da vossa carne, vos vivificou juntamente com ele, perdoando-vos todas as ofensas" (Colossenses 2:11-13), ressaltando a importância do batismo, que marca a morte para o mundo e a ressurreição para uma nova vida com Cristo pelo poder de Deus, algo que é dado ao que crê, arrepende-se e é batizado (BÍBLIA ON-LINE, 2021);

- "Porque todos sois filhos de Deus pela fé em Cristo Jesus. Porque todos quantos fostes batizados em Cristo já vos revestistes de Cristo" (Gálatas 3:26,27), mostrando a importância da fé para ser filho e do batismo para recebimento do Espírito Santo (BÍBLIA ON-LINE, 2021).

3a Matéria: "O batismo salva?” (PERSONA, 2016). 
O interlocutor defendeu a crença de que tudo depende do que a pessoa entende por salvação, pois a palavra batismo, quando aparece em alguns versículos associada à salvação, como 1 Pedro 3:21, não quer dizer a salvação da alma (anulação de uma pena judicial), mas a salvação "das coisas que nos cercam... das coisas ao nosso redor" (minuto 0:28) (BÍBLIA ON-LINE, 2021).

Trata-se de algo que, na visão do interlocutor, coloca o cristão em uma nova esfera de responsabilidade, como ocorre, por exemplo, com as nações que se dizem cristãs (como as da Europa), em relação às pagãs (Índia e China), as quais terão maior culpa no dia do juízo do que as nações pagãs. Para tanto, ele baseia suas afirmações nos seguintes versos:

- "Porque pela graça sois salvos, por meio da fé; e isto não vem de vós, é dom de Deus. Não vem das obras, para que ninguém se glorie" (Efésios 2:8,9), palavras que, segundo o autor, asseguram que o único meio de graça é a fé em Cristo, sem necessidade de realizar qualquer outra coisa, incluindo o batismo (BÍBLIA ON-LINE, 2021).

4 Matéria: "Batismo \& Salvação" (SAVIOLI, 2017).

O interlocutor defendeu a crença de que basta entender o propósito do batismo para perceber que se trata de um simbolismo de algo que já ocorreu por ocasião da conversão da pessoa (minuto 1:40). Tal simbolismo representa, para quem é batizado: arrependimento, morte, sepultamento e ressurreição (Romanos 6:3-5); já para quem o assiste, o batismo representa tão somente um testemunho público da fé em Cristo (1 João 2:23) (BÍBLIA ON-LINE, 2021).

O autor respaldou sua posição nos seguintes versos bíblicos, que, segundo ele, comprovam que quem salva é a fé e não o batismo, o qual serve apenas como identificação com a Obra de Cristo: 
- "Porque pela graça sois salvos, por meio da fé; e isto não vem de vós, é dom de Deus. Não vem das obras, para que ninguém se glorie" (Efésios 2:8,9) (BÍBLIA ONLINE, 2021);

- "Todo aquele que crê que Jesus é o Cristo, é nascido de Deus..." (1 João 5:1,2) (BÍBLIA ON-LINE, 2021).

5a Matéria: "O batismo salva?" (GRANCONATO, 2020).

O interlocutor defendeu a ideia de que a regeneração batismal é uma doutrina falsa (minuto 0:06), pois, segundo ele, o batismo representa tão somente um ritual simbólico (minuto 2:42), com base nos seguintes versos:

- "Aquele que crê no Filho tem a vida eterna; mas aquele que não crê no Filho não verá a vida, mas a ira de Deus sobre ele permanece" (João 3:36), excluindo a necessidade do batismo como um ato salvífico (BÍBLIA ON-LINE, 2021);

- "Porque Deus amou o mundo de tal maneira que deu o seu Filho unigênito, para que todo aquele que nele crê não pereça, mas tenha a vida eterna" (João 3:16), ressaltando a necessidade única da fé para a salvação (BÍBLIA ON-LINE, 2021);

- "Tendo sido, pois, justificados pela fé, temos paz com Deus, por nosso Senhor Jesus Cristo" (Romanos 5:1), ressaltando a necessidade única da fé para a justificação e para a adoção como filho e herdeiro das promessas (minuto 4:42) (BÍBLIA ON-LINE, 2021).

6 Matéria: "O Batismo Cristão" (SILVA, Rodrigo, 2014).

O interlocutor defendeu a crença de que o batismo cristão é um rito de admissão ao corpo de Cristo, simbolizando a morte (o deitar nas águas), o sepultamento (a morte para o mundo) e a ressurreição (o levantar em novidade de vida) do novo convertido (minuto 18;00). Externamente, representa uma demonstração pública (exterior) daquilo que aconteceu no coração (no interior), como sendo o casamento público do cristão com seu esposo, Cristo (minuto 26:53). 
$\mathrm{Na}$ sua visão, a rigidez na prática do batismo, por parte da igreja primitiva, está ligada às perseguições que os cristãos sofreram naquele período, havendo necessidade de mostrar, publicamente, disposição de sofrer pela Obra de Cristo (um compromisso verdadeiro).

7ª̣ Matéria: "A importância do batismo nas águas" (TÉRCIO, 2017).

O interlocutor defendeu a crença de que o batismo é um "sacramento" /ordenança (minuto 0:18), de tal forma que o mergulho tem poder para dar ao cristão as características de Cristo (um revestimento).

Logo, na sua visão, trata-se de algo sobrenatural (minuto 9:43) que ultrapassa as questões de identificação e confissão pública, as quais também estão presentes no ato batismal. Representa, portanto, algo poderoso que é feito na terra, com grande repercussão no céu.

8a Matéria: "Batismo: O começo de Uma Nova Vida" (HOOSER, 2021)

O interlocutor defendeu a crença de que para receber a vida eterna (o maior presente que o homem poderia receber de Deus) é necessário alcançar previamente o perdão dos pecados e desfrutar da presença do Espírito Santo, os quais só são possíveis mediante duas ações exclusivamente humanas: o arrependimento e a fé (Marcos 1:15) (BÍBLIA ON-LINE, 2021).

Segundo o autor, tal verdade fica evidenciada na passagem do Livro de Atos, em que aqueles que ouviram a pregação do apóstolo Pedro, e tiveram seus corações tocados pela Palavra de Deus, fizeram a seguinte pergunta: "Que faremos, homens irmãos?" (Atos 2:37) (BÍBLIA ON-LINE, 2021), indicando uma providência (ação).

Para o interlocutor, acima da questão simbólica (morte e ressurreição), o batismo é um requisito para: (1) Receber o perdão dos pecados, o qual é recebido mediante a "confissão pública e o compromisso de fé em Jesus Cristo como Salvador e Senhor" (Lucas 6:46) (BíBLIA ON-LINE, 2021); e (2) Receber o Espírito Santo como 
condição sine qua non para a salvação, uma vez que, quem não $O$ possui, não pertence a Deus (Romanos 8:9) (BÍBLIA ON-LINE, 2021).

9a Matéria: “CCB - O batismo salvífico da Congregação Cristã” (AMARAL, 2011).

O interlocutor afirmou que o ministério da Congregação Cristã no Brasil está errado por considerar o batismo cristão salvífico (o primeiro passo para a salvação), entendendo que o fundador da igreja, Louis Francescon, já estava salvo quando foi batizado por imersão na igreja presbiteriana (donde veio), que acredita na máxima "uma vez salvo, salvo para sempre" (XAVIER, [s.d.]).

O autor assegura que Jesus não pregou sobre o batismo durante seu ministério, tendo citado algo apenas no final do Seu ministério terreno (Marcos 16:16 e Mateus 28:19) (BÍBLIA ON-LINE, 2021).

$\mathrm{Na}$ sua visão, alguns versos mostram claramente que a salvação depende unicamente da fé, tal como: "Aquele que crê no Filho tem a vida eterna; mas aquele que não crê no Filho não verá a vida, mas a ira de Deus sobre ele permanece" (João 3:36) (BÍBLIA ON-LINE, 2021). Por não conter a palavra "batismo", tal passagem revela que há necessidade apenas da fé.

O interlocutor citou o caso de Zaqueu para justificar sua posição (Lucas 19:1-10) (BÍBLIA ON-LINE, 2021), na qual Jesus falou em salvação sem citar a palavra batismo, algo que se repetiu em outras duas passagens: (1) Quando Jesus curou uma mulher com fluxo de sangue (Mateus 9:20-22) (BÍBLIA ON-LINE, 2021); e (2) Quando Ele expulsou uma legião de demônios de um gadareno (Marcos 5:1-20) (BÍBLIA ON-LINE, 2021). Em ambas, segundo o autor, a salvação ocorreu exclusivamente pela fé, desacompanhada da necessidade de batismo.

10ª Matéria: "Batismo Apostólico x Trinitariano" (SCHMIDT, 2019).

O interlocutor defendeu a crença de que o batismo tem como finalidade o perdão e a remissão dos pecados (minuto 11:26), devendo ser realizado "em nome do Senhor 
Jesus Cristo", pois só nesse nome há remissão e salvação, conforme os seguintes versículos:

- "E em seu nome se pregasse o arrependimento e a remissão dos pecados, em todas as nações, começando por Jerusalém" (Lucas 24:47) (BÍBLIA ON-LINE, 2021);

- "E em nenhum outro há salvação, porque também debaixo do céu nenhum outro nome há, dado entre os homens, pelo qual devamos ser salvos" (Atos 4:12) (BÍBLIA ON-LINE, 2021).

- "A este dão testemunho todos os profetas, de que todos os que nele crêem receberão o perdão dos pecados pelo seu nome" (Atos 10:43) (BÍBLIA ON-LINE, 2021).

11a Matéria: "A Verdade sobre o Batismo" (GONÇALVES, 2018).

O interlocutor defendeu a crença de que o batismo tem relação direta com a salvação, sendo importante crer e ser batizado para ter acesso direto ao céu (minuto $0: 44$ e $3: 59)$.

Segundo o autor, no momento do batismo, o Espírito Santo desce sobre a pessoa e Deus declara, no céu, diante dos anjos, as mesmas palavras que disse a respeito de Jesus Cristo, quais sejam: "este é meu filho amado em quem me comprazo" (minuto 4:09 e 4:13). Assim como as águas batismais representaram o início do ministério de Jesus Cristo, o batismo dos cristãos marca o primeiro passo de uma caminhada com Cristo (minuto 5:48), na visão do autor.

Para embasar seus argumentos, o interlocutor apresentou os seguintes versos:

- "Quem crer e for batizado será salvo; mas quem não crer será condenado" (Marcos 16:16) (BÍBLIA ON-LINE, 2021); e 
- "E, sendo Jesus batizado, saiu logo da água, e eis que se the abriram os céus, e viu o Espírito de Deus descendo como pomba e vindo sobre ele. E eis que uma voz dos céus dizia: Este é o meu Filho amado, em quem me comprazo" (Mateus 3:16,17) (BÍBLIA ON-LINE, 2021).

12ª Matéria: "Basta Crer Para Ser Salvo?" (ASHELEY, 2015).

O interlocutor defendeu a obediência como condição para alcançar a salvação, sem a qual a seguinte passagem bíblica perde totalmente o sentido: "Ainda que era Filho, aprendeu a obediência, por aquilo que padeceu. E, sendo ele consumado, veio a ser a causa da eterna salvação para todos os que the obedecem" (Hebreus 5:8,9) (BÍBLIA ON-LINE, 2021).

Para o autor, fé e obediência andam de mãos dadas, algo ratificado por Tiago que mostrou em sua carta que as obras de obediência (que resultam da fé) mantêm o relacionamento do cristão com Deus: "Mas, ó homem vão, queres tu saber que a fé sem as obras é morta? Porventura o nosso pai Abraão não foi justificado pelas obras, quando ofereceu sobre o altar o seu filho Isaque? Bem vês que a fé cooperou com as suas obras, e que pelas obras a fé foi aperfeiçoada" (Tiago 2:20-22) (BÍBLIA ON-LINE, 2021).

O batismo, para o autor, além de simbolizar a condenação à morte da antiga forma de viver, representa o momento em que o cristão é adotado como filho, pelo recebimento do Espírito Santo, conforme mostra o apóstolo Pedro: "Arrependei-vos, e cada um de vós seja batizado em nome de Jesus Cristo, para perdão dos pecados; e recebereis o dom do Espírito Santo" (Atos 2:38) (BÍBLIA ON-LINE, 2021).

No que se refere à perseverança, o autor citou as palavras de Jesus, afirmando a necessidade de perseverar até o fim para ser salvo (Mateus 10:22 e Mateus 24:13) (BÍBLIA ON-LINE, 2021), algo confirmado pelo apóstolo Paulo na seguinte passagem: "Antes subjugo o meu corpo, e o reduzo à servidão, para que, pregando 
aos outros, eu mesmo não venha de alguma maneira a ficar reprovado" (1 Coríntios 9:27) (BÍBLIA ON-LINE, 2021).

13 $3^{a}$ Matéria: "EM POUCAS PALAVRAS: o que significa "quem crer e for batizado será salvo"?" (NICODEMUS, 2021)

O interlocutor defendeu a ideia de que somente no tempo da igreja primitiva é que a conversão ocorria no momento do batismo (minuto 0:06), dando uma falsa impressão de que o batismo é salvífico (minuto 0:18).

Contudo, na sua visão, a Bíblia é muita clara em afirmar que os cristãos são salvos unicamente mediante a fé, de tal forma que o batismo é semelhante à circuncisão, que representava tão somente um símbolo da aliança de Deus com o povo de Israel (minuto 0:51).

14 Matéria: "A heresia da salvação pelo batismo da CCB - Testemunho mirabolante para oprimir os jovens no Batismo" (AGRA, 2021).

O interlocutor usou uma pregação feita na Congregação Cristã no Brasil (CCB), para defender a crença de que o batismo não é salvífico, citando, no minuto 5:58, o caso do ladrão da cruz, o qual, mesmo não sendo batizado, foi salvo por Jesus.

Disse, no minuto 6:29, que um cristão da CCB, envolvido no batismo de uma pessoa acamada, citado pelo pregador, era praticamente "uma pessoa salvífica", por sentirse responsável pelas providências batismais, condenando-o por tal sentimento.

Assegurou, no minuo 6:50, que Cristo não irá cobrar o batismo de quem está acamado, sugerindo que os esforços realizados para batizar tal pessoa (citada pelo pregador) foram em vão.

Em seguida, o autor fez um paralelo novamente com o ladrão da cruz, afirmando que, se houvesse necessidade do batismo (do ladrão) para ser salvo, "Deus tinha que ter feito um reboliço para a arrancar ele (o ladrão) de lá, batizar e pendurar ele de novo" (minuto 6:58). Com isso, como um crítico da CCB, o interlocutor terminou 
por desmerecer a crença de que o batismo é um meio de graça para perdoar pecados e, consequentemente, para salvar o pecador arrependido.

Na sequência da matéria, o autor afirmou que o batismo é apenas um mandamento de Jesus e que a salvação depende unicamente da fé (minuto 14:24). Para tanto, ele fez outro paralelo com a passagem em que Jesus curou um cego, mandando-o lavar-se no tanque de Siloé (João 9:1-10), assegurando que isso ocorreu somente porque o tal cego tinha condições de fazê-lo (BÍBLIA ON-LINE, 2021).

Segundo o autor, tal batismo (da mulher acamada) só ocorreu porque o pessoal da CCB não encontrou um médico convertido, que iria dizer-Ihes: "Você tá maluco, amigo. Quem disse que precisa batizar para ser salvo?" (minuto 17:20).

Por fim, o autor expõe um dizer na matéria com as seguintes palavras: "Heresia absurda de salvação por obras: pior do que a salvação por obras é a salvação por terceiros", desqualificando, também, a necessidade de perseverança dos santos e a participação ativo do homem no processo de santificação, sem a qual ninguém verá a Deus (Hebreus 12:14) (BÍBLIA ON-LINE, 2021).

15 Matéria: "A CCB BATIZA PESSOAS DE OUTRAS IGREJAS? ISSO É BÍBLICO? SIM! E SAIBA O PORQUÊ!" (HEINAR, 2019).

O interlocutor defendeu a crença de que a Congregação Cristã no Brasil (CCB) rebatiza corretamente os crentes de outras denominações religiosas, pois as mesmas, donde vieram, não seguem a doutrina de Jesus Cristo, de sorte que seus batismos são inválidos (minuto 3:36), pois seus ministros não possuem autoridade para batizá-los.

Para ele, o batismo deve ser realizado em nome de Jesus Cristo, conforme afirmam diversos versículos bíblicos, a exemplo do que o apóstolo Paulo recomenda na sua carta aos colossenses: "E, quanto fizerdes por palavras ou por obras, fazei tudo em nome do Senhor Jesus, dando por ele graças a Deus Pai" (Colossenses 3:17) (BÍBLIA ON-LINE, 2021). 
Dessa forma, o autor acredita que o rebatismo é bíblico (minuto 6:50), à semelhança do que fez o apóstolo Paulo quando encontrou em Éfeso alguns cristãos que haviam sido batizados apenas no batismo de João, os quais, por causa disso, ainda não tinham recebido o Espírito Santo.

A narrativa bíblica mostra que o apóstolo ensinou aos efésios a doutrina apostólica e os batizou em nome de Jesus Cristo, permitindo-Ihes receber, de forma sobrenatural, o Espírito Santo, com a imposição das suas mãos. Com essa citação, o autor fez uma ligação entre o batismo e a salvação, algo que já havia feito no minuto 4:35, quando afirmou que o batismo tem a finalidade de dar a remissão e o perdão dos pecados.

\section{ANÁLISE E DISCUSSÃO DOS DADOS}

Os dados numéricos relacionados ao entendimento dos autores sobre o batismo (se ele possui ou não implicações salvíficas) foram bastante equilibrados, conforme mostra o Gráfico 1.

$53 \%$ dos autores selecionados disseram crer que o batismo tem implicações salvíficas, enquanto $47 \%$ acreditam que não. 
Gráfico 1: Implicações salvíficas do batismo

\section{O batismo tem ou não implicações salvíficas?}

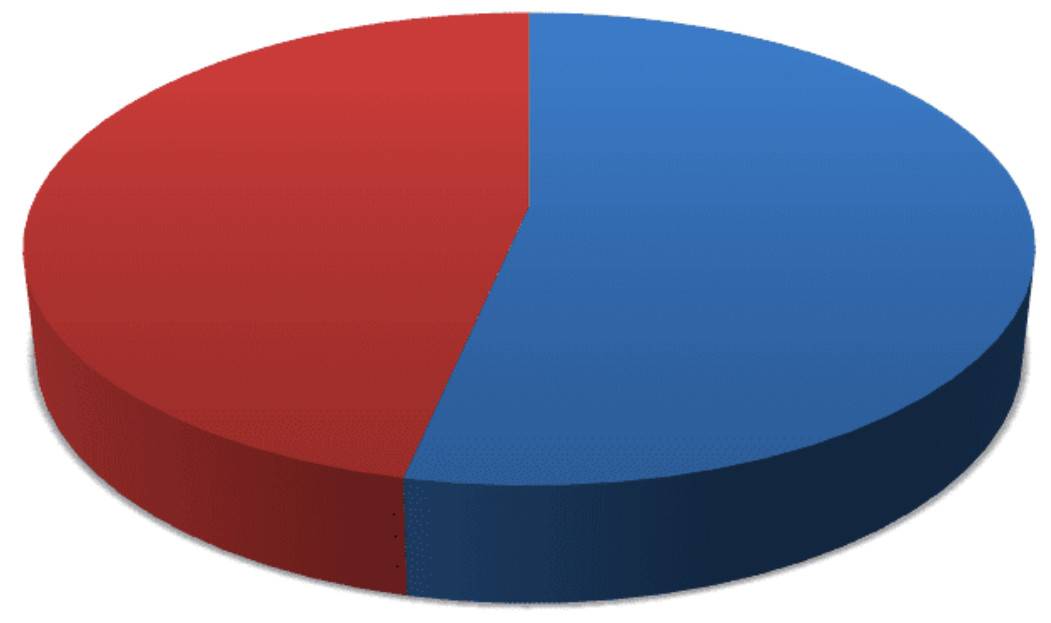

— Sim — Não

Nota: elaborado pelo autor.

No que se refere à análise qualitativa das informações, a totalidade dos que disseram entender que o batismo não possui implicação salvífica desconsiderou o fato de Marcos 16:16 ("quem crer e for batizado") apresentar uma conjunção coordenativa aditiva (a letra "e"), que traz a ideia de soma, de adição (uma coisa mais a outra) (BÍBLIA ON-LINE, 2021; ROCHENBACH, 2017).

Dessa forma, os tais acabaram por qualificar a fé como único meio de graça para alcançar a salvação, desprezando o batismo. Contudo, conforme nos mostra o Manual Popular de Dúvidas, Enigmas e "Contradições da Bíblia", há uma regra matemática infalível que diz o seguinte: "onde quer que haja dois, sempre há um - e nisso não existe erro!" (grifo do autor) (GEISLER e HOWE, 1999, p. 16).

Tal regra diz respeito à Teoria dos Conjuntos, cujo postulado define, entre outras coisas, quais elementos pertencem ou não a um determinado conjunto. No caso em pauta neste artigo, trata-se de um conjunto formado por dois elementos ("fé" e "batismo"), os quais definem quais pessoas serão salvas (FRANÇA, 2014). 
Assim sendo, ainda que haja várias passagens que digam que a salvação está condicionada à fé, nem por isso se pode descartar a clareza das palavras ditas por Jesus ("crer e ser batizado"). Isto é, ainda que haja versículos que citem apenas a fé como salvífica, isso não exclui, em absoluto, o outro elemento do mesmo conjunto (o batismo), pois "onde há dois, há um" (grifo do autor) (GEISLER e HOWE, 1999).

Uma ilustração que pode ajudar a compreender melhor a regra matemática, acima referenciada, é a seguinte: se dissermos que Pedro subiu ao monte onde Jesus transfigurou-se (fato narrado em Mateus 17:1-2) e não citarmos João e Tiago, os quais, segundo o relato bíblico, também subiram, não significa um erro, pois Pedro subiu de fato. Seria um erro se disséssemos que só Pedro subiu ao monte com Jesus, pois isso seria uma inverdade.

Portanto, citar apenas o nome de Pedro não é um erro e tão pouco significa dizer que ele estava sozinho, pois, como foi dito acima, "onde há dois, há um" (grifo do autor) (GEISLER e HOWE, 1999).

No que se refere à Lógica (deixando as crenças teológicas de lado), as proposições feitas por Jesus ("Quem crer e for batizado será salvo") apontam para um conectivo condicional ("se... então"), ou seja, a segunda proposição só acontece se a primeira for verdadeira. Assim sendo, sem fé e sem batismo, a segunda proposição é falsa: não há salvação (PROCÓPIO, 2020; TRIGO, s/d).

O mesmo raciocínio pode ser usado para os dois elementos que formam a primeira proposição feita por Jesus ("crer" e "ser batizado"). Se faltar um deles, tal proposição, do ponto de vista da Lógica, também é considerada falsa por causa do conectivo "e" (PROCÓPIO, 2020).

Além dessas verdades, não há como ignorar as passagens bíblicas que fazem uma conexão direta da "remissão dos pecados" e do "recebimento do Espírito Santo" com o batismo, como, por exemplo, as palavras ditas pelo cristão Ananias ao apóstolo Paulo: "Levanta-te, e batiza-te, e lava os teus pecados, invocando o nome do Senhor" (Atos 22:16). Negligenciar tal verdade certamente não é a melhor saída 
para justificar a descrença na conjunção condicional que existe entre salvação e batismo.

Aliás, se não houvesse tal conexão, como seriam justificados os versos que mostram, de forma clara, a ação sobrenatural que ocorria no batismo na época da igreja primitiva, com manifestações divinas visíveis e audíveis (Atos 10:47; Atos 19:5-6; Gálatas 3:27) (BÍBLIA ON-LINE, 2021)?

Será que qualificar tais fatos bíblicos como algo exclusivo da igreja primitiva (como

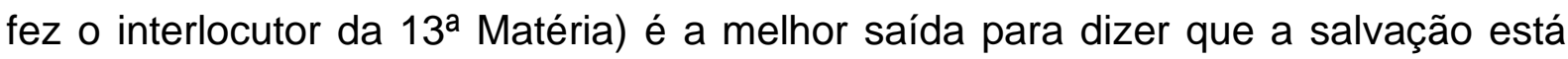
condicionada unicamente à fé? Seguramente não, pois não há nada nas Escrituras Sagradas que garanta que os sinais eram exclusivos para os cristãos daquela época; ao contrário, Jesus Cristo prometeu que as ações sobrenaturais (as manifestações do Espírito Santo) acompanhariam todos os que cressem (Marcos 16:17) (BÍBLIA ON-LINE, 2021).

Mesmo o caso do salteador que foi salvo por Jesus na cruz do Calvário, sem o batismo (Lucas 23:43), não invalida a regra estabelecida por Jesus para a salvação, visto que: (1) As condições não permitiam que o batismo fosse realizado (cada caso é um caso); e (2) A ordem do batismo para remissão dos pecados e recebimento do Espírito Santo ainda não havia sido dada por Jesus, vindo só depois que o salteador já havia morrido (PIRES, 2017). Em termos de Lógica, a salvação do salteador encontra respaldo no fato de Jesus não ter usado um conectivo bicondicional ("se e somente se"). Se houvesse bicondicionalidade, Jesus estaria impedido de dar-Ihe a salvação sem o batismo.

Alguns estudiosos sugerem que o fato de Jesus ter dito, em Marcos 16:16, "quem não crer será condenado", sem mencionar o batismo, é a garantia de que não existe relação condicional entre salvação e batismo. Contudo, o verso parece, tão somente, indicar a ordem natural dos elementos para que a salvação aconteça: primeiro vem a fé e depois o batismo. 
Há uma passagem bíblica que parece confirmar tal argumento, mostrando a importância do batismo na vida do cristão. Trata-se dos versos que relatam a evangelização de um Eunuco por parte do evangelista Felipe, citada em Atos 8:2639 (BÍBLIA ON-LINE, 2021).

Ao ouvir a pregação de Felipe, o Eunuco faz-Ihe a seguinte pergunta: "Eis aqui água; que impede que eu seja batizado?" (Atos 8:36). Tal questionamento, sugere, de forma clara, que a pregação do evangelista foi voltada para a "remissão dos pecados" e para o "recebimento do Espírito Santo", os quais ocorrem por ocasião do batismo, segundo ensina o apóstolo Pedro nestes termos: "Arrependei-vos, e cada um de vós seja batizado em nome de Jesus Cristo, para perdão dos pecados; e recebereis o dom do Espírito Santo" (Atos 2:38) (BÍBLIA ON-LINE, 2021).

Depois de ouvir tais verdades, só então é que Felipe anuncia, ao Eunuco, a fé em Jesus Cristo como condição para ser batizado: "É lícito (o batismo), se crês de todo o coração" (Atos 8:37) (BÍBLIA ON-LINE, 2021). Ao confessar que cria, o evangelista fez, então, o batismo do Eunuco.

Portanto, quando Jesus usou a expressão "quem não crer será condenado", Ele estava ensinando, tão somente, que o processo da salvação começa pela fé, vindo, depois disso, a remissão dos pecados e o recebimento do Espírito Santo pelo batismo (APOTOLI CRISTI, s/d).

Uma comparação que pode ajudar na compreensão de tal verdade é o que ocorre quando alguém ofende outra pessoa e arrepende-se do erro cometido. Apesar de ter havido arrependimento, a extinção da culpa só ocorre, de fato, quando o ofensor pede perdão ao ofendido (CURY, 2014).

Antes do pedido formal de perdão (por uma ofensa), a culpa permanece, conforme ensinou Jesus Cristo: "Portanto, se trouxeres a tua oferta ao altar, e aí te lembrares de que teu irmão tem alguma coisa contra ti, deixa ali diante do altar a tua oferta, e vai reconciliar-te primeiro com teu irmão e, depois, vem e apresenta a tua oferta" (Mateus 5:23,24) (BÍBLIA ON-LINE, 2021). 
Dessa forma, ainda que uma pessoa compreenda que é pecadora e creia em Jesus como seu salvador, só depois que ela confessa publicamente o seu arrependimento, nas águas do batismo, é que a culpa é desfeita e o Espírito Santo lhe é dado como sinal da aceitação por parte de Deus: "Deus com a sua destra o elevou a Príncipe e Salvador, para dar a Israel o arrependimento e a remissão dos pecados. E nós somos testemunhas acerca destas palavras, nós e o Espírito Santo, que Deus deu àqueles que lhe obedecem" (Atos 5:31,32) (BÍBLIA ON-LINE, 2021).

Logo, assim como o batismo de Jesus Cristo, no Rio Jordão, representou o marco da Sua união íntima com o Pai, selada pela descida do Espírito Santo (Mateus 3:16; 12:18) (BÍBLIA ON-LINE, 2021; NASCIMENTO, 2020c), da mesma forma, o batismo cristão é o marco da aliança entre a criatura (genuinamente convertida) e o Criador, pela presença viva do mesmo Espírito, que, como regra, desce do céu no momento sublime da imposição de mão do presbítero, no batismo (SILVA, 2009; RODRIGUES, 2018).

Muito embora o tema seja empolgante e desafiador, é preciso ter em mente que não existe quaisquer contradições nos textos bíblicos. O teólogo Natan Rufino, em sua obra Uma vez salvo, salvo para sempre?, chamou a atenção dos leitores para a seguinte verdade: "o uso da inteligência ao se argumentar em defesa de uma doutrina infundada não a transforma numa verdade bíblica" (RUFINO, 2012).

\section{CONCLUSÃO}

As justificativas apresentadas pelos interlocutores que disseram que o batismo não tem implicações salvíficas acabam por desconsiderar as regras da língua portuguesa e da matemática, ora apresentadas, dando espaço para a propagação de ideias incongruentes, que mudam totalmente o sentido dos textos bíblicos (GEISLER e HOWE, 1999).

Ao ignorar essas regras básicas, os interlocutores acabam por induzir os cristãos a dizerem aquilo que a Bíblia não diz, podendo recair sobre si as palavras ditas por Jesus aos fariseus da Sua época, quando disse-Ihes que eles não entravam no reino 
dos céus e não deixavam os outros entrar também (Mateus 23:13) (BÍBLIA ONLINE, 2021).

Tais regras, salvo melhor juízo, asseguram que existe, de fato, uma participação ativa do cristão nos processos de salvação e de santificação, iniciados no batismo. O uso dos verbos no infinitivo em Marcos 16:16 ("crer" e "ser batizado"), aponta para duas atitudes (obras) que devem ser tomadas por aqueles que ouvem as boas novas de salvação (FILGUEIRAS, 2018).

Portanto, parece ficar claro que, embora a fé seja o fundamento do cristianismo, contudo, não basta crer para ser salvo, sendo necessário colocar-se à disposição do Espírito Santo para que, ajudado por Ele, o cristão possa, a partir do batismo, produzir os frutos dignos de arrependimento (obras da fé), sem os quais a fé é morta (Tiago 2:17) (BÍBLIA ON-LINE, 2021).

O próprio apóstolo Paulo confirmou a veracidade de tais argumentos ao dizer, na carta aos coríntios, que procurava continuamente subjugar sua natureza humana para que não viesse, de alguma forma, a ser reprovado, denotando a necessidade de perseverança por parte dos cristãos (1 Coríntios 9:27) (BÍBLIA ON-LINE, 2021).

\section{REFERÊNCIAS}

AGRA, Josafá. A heresia da salvação pelo batismo da CCB - testemunho mirabolante para oprimir os jovens no batismo. Canal CCB sem Censura, 2021. Disponível em: https://www.youtube.com/watch?v=u1jdwvrHSi4. Acesso em: 20/08/2021.

AMARAL, J. F. CCB - O batismo salvífico da congregação cristã. Canal do YouTube Jahyr Ferreira do Amaral, 2011. Disponível em: $<$ https://www.youtube.com/watch?v=fP5XdQbyBSc>. Acesso em: 21/08/2021.

APOSTOLI CRISTI. O batismo é necessário para a salvação. S/d. Disponível em: <https://www.apostolichrist.com/obatismo-e-necessario-para-a-salvac>. Acesso em: 25/09/2021. 
ASHELEY, Scott. Basta crer para ser salvo? A Boa Nova, p. 16-17, 2015. Disponível em: <https://portugues.ucg.org/a-boa-nova/basta-crer-para-ser-salvo>. Acesso em: 02/09/2021.

BARROS, J. F. F. Quem crê e for batizado, será salvo! Canal do YouTube Rede Século 21, 2017. Disponível em: <https://www.youtube.com/watch?v=R0RwHLKR1ac>. Acesso em: 03/09/2021.

BERTI, Marcelo. Soteriologia: doutrina da salvação. São Paulo, Brasil: Blog Teologando, 2015.2 Disponível em: <https://marceloberti.files.wordpress.com/2010/02/apostila-teologia-sistematicasoteriologia.pdf>. Acesso em: 10/08/2021.

BÍBLIA ON-LINE. Bíblia Sagrada. [S.I.]: Versões Almeida Corrigida e Fiel/Nova Versão Internacional/Nova Almeida Atualizada., 2021. Disponível em: <https://www.bibliaonline.com.br/>. Acesso em: 10/08/2021 a 20/09/2021.

BRASILINO, G. M. O Batismo bíblico salva | Regeneração Batismal. Canal do YouTube Sinal de Graça, 2018. Disponível em: <https://www.youtube.com/watch?v=cbczxGKtyEQ>. , 2018. Acesso 07/09/2021.

CARVALHO, M. S. Presenças do platonismo em Agostinho de Hipona (354-430 ) (nos 1600 anos das “Confissões”). Revista Filosófica de Comibra, v. 9, n. 18, p. 289-307, 2000. Disponível em: <https://digitalisdsp.uc.pt/bitstream/10316.2/34393/1/RFC18_artigo3.pdf?ln=pt-pt>. Acesso em: 25/08/2021.

CERVO, A. L.; BERVIAN, P. A.; SILVA, R. Metodologia científica. 6. ed. São Paulo, Brasil: Pearson Prentice Hall, 2007.

CURY, Rogério. A extinção da punibilidade pelo perdão do ofendido aceito. Site Jusbrasil, 2014. Disponível em: https://rogeriocury.jusbrasil.com.br/artigos/148018758/a-extincao-da-punibilidadepelo-perdao-do-ofendido-aceito>. Acesso em: 22/09/2021. 
FILGUEIRAS, Gabriel. 7 atitudes que agradam a Deus (muitos desprezam a $7^{\mathrm{a}}$ ). Blog Bíblia se Ensina, 2018. Disponível em: <https://bibliaseensina.com.br/atitudesque-agradam-a-deus/>. Acesso em: 23/09/2021.

FRANÇA, M. V. D. Conjuntos - operações - relações de pertinência e inclusão. Site Uol Resolve, 2014. Disponível em: $<$ https://educacao.uol.com.br/disciplinas/matematica/conjuntos---operacoesrelacoes-de-pertinencia-e-inclusao.htm >. Acesso em: 10/09/2021.

FURTADO, F.C.; BEZERRA, C.A. Uma introdução ao molinismo. Revista Ensaios Teológicos, v. 3, n. 1, p. 89-102, 2017.

GASTON, James. O papel fundamental do cristianismo na cultura ocidental. Blog É Realizações, 2020. Disponível em: <https://www.erealizacoes.com.br/blog/opapel-fundamental-do-cristianismo-na-cultura-ocidental/>. Acesso em: 15/09/2021.

GEISLER, Norman; HOWE, Thomas. Manual popular de dúvidas, enigmas e "contraições da Bíblia". São Paulo: Mundo Cristão, 1999.

GONÇALVES, Luis. A verdade sobre o batismo. Canal do YouTube Adventistas Brasil, 2018. Disponível em: <https://www.youtube.com/watch?v=DwwolAXKdi0>. Acesso em: 12/09/2021.

GRANCONATO, Marcos. O batismo salva?. São Paulo: Canal do YouTube Igreja batista Redenção, 2020.2 Disponível em: <https://www.youtube.com/watch?v=RYrp76yluAs>. Acesso em: 17/08/2021.

HEINAR, Carlos. A CCB batiza pessoas de outras igrejas? Isso é bíblico? Sim! E saiba o porquê! Canal Carlos Heinar, 2019. Disponível em: < https://www.youtube.com/watch?v=PwVvvNO4quE>. Acesso em: 19/08/2021. 
HOOSER, D. Batismo: o começo de uma nova vida. A Boa Nova, p. 18-19, 2021. Disponível em: <https://portugues.ucg.org/revista-boa-nova/batismo-o-comeco-deuma-nova-vida>. Acesso em: 19/08/2021.

KUNRATH, Pedro Alberto. Renovação interior do ser humano e sua deificação/santificação. Teocomunicação, v. 37, n. 158, p. 571-585, 2007. Disponível em: <file://C:/Users/Marcelo/Downloads/Renovacao_interior_do_ser_humano_e_sua_de ificacaos.pdf>. Acesso em: 30/08/2021.

LOTT, Henrique Marques. A soteriologia e os diferentes critérios de salvação em Luc Ferry. Sacrilegens, v. 7, n. 1, p. 91-101, 2010. Disponível em: <file://C:/Users/Marcelo/Downloads/26714-Texto do artigo-105845-1-1020190608.pdf>. Acesso em: 02/09/2021.

MELLO, Ildo. O que é a santificação? Canal Ildo Mello, 2020. Disponível em: <https://www.youtube.com/watch?v=DokZZ-JOqH4>. Acesso em: 04/09/2021.

Palestra sobre a inteira antificação - Parte 1. Canal lldo Mello, 2016. Disponível em: <https://www.youtube.com/watch?v=2kPPwUVtZ6Y>. Acesso em: 04/09/2021.

NASCIMENTO, Marcelo Victor Rodrigues. O atributo divino do livre-arbítrio. Joinville, Brasil: Clube de Autores, 2020a. Disponível em: $<$ https://clubedeautores.com.br/livros/autores/marcelo-victor-rodrigues-donascimento\%0Allustração>. Acesso em: 04/09/2020.

O conhecimento médio e a auto-existência de Deus. Revista Sociedade

Científica, v. 3, n. 6, p. 1-15, 2020 b.

. Um só batismo, em nome de Jesus Cristo. Joinville, Brasil: Clube de Autores, 2020c. Disponível em: $<$ https://clubedeautores.com.br/livros/autores/marcelo-victor-rodrigues-donascimento>. Acesso em: 05/09/2021. 
NICODEMUS, Augustus. Em poucas palavras: o que significa " quem crer e for batizado será salvo "? Canal Augustus Nicodemus Lopes, 2021. Disponível em: <https://www.youtube.com/watch?v=ooeuH8Smh1Q>. Acesso em: 09/09/2021.

PALÁCIO, M. Soteriologia. Votuporanga, SP: FATEC, 2010. Disponível em: <http://www.fatecc.com.br/alunos/apostilas/teologia/4periodo/soteriologia.pdf>. Acesso em: 06/09/2021.

PEIXOTO, Leandro. Razões para crer em Jesus Cristo. Segunda Igreja Batista de Goiânia, 2017. Disponível em: <https://www.sibgoiania.org/sermao/razoes-para-crerem-jesus-cristo/>. Acesso em: 06/09/2021.

PERSONA, Mario. O batismo salva? Canal do YouTube Respondi.com.br, 2016. Disponível em: <https://www.youtube.com/watch?v=s7QHZY6uYhs>. Acesso em: 02/09/2021.

PROCÓPIO, Rafael. Conectivos lógicos "se então" e "se e somente se" e tabela verdade | Curso de RLM | Aula 07. Canal Matemática Rio com Prof. Rafael Procópio, 2020.2 Disponível em: <https://www.youtube.com/watch?v=u6C_RHwMJI8>. Acesso em: 20/09/2021.

ROCHENBACH, Wilson. Conjunção - Aula 1 (Coordenativas - Aditivas). Canal Prof. Wilson Rochenbach, 2017.2 Disponível em: <https://www.youtube.com/watch?v=C-oAYkx7FOs>. Acesso em: 20/09/2021.

RODRIGUES, Arnaldo. Os efeitos do Batismo. Site Vatican News, 2018. Disponível em: <https://www.vaticannews.va/pt/igreja/news/2018-04/batismo-efeitosreflexao-padre-arnaldo-rodrigues.html>. Acesso em: 26/08/2021.

RODRIGUES, W. N. O desafio da Santificação. Blog Pregações e Estudos Bíblicos, 2017. Disponível em: <https:/www.esbocosermao.com/2017/01/o-desafioda-santificacao.html>. Acesso em: 27/08/2021. 
ROHREGGER, Roberto. A influência da religião na sociedade. Site Central de Notícias Uinter, 2020. Disponível em: <https://www.uninter.com/noticias/a-influenciada-religiao-na-sociedade>. Acesso em: 28/08/2021.

RUFINO, Natan. Uma vez salvo, salvo para sempre? 1. ed. Belo Horizonte: Promove Artes Gráficas e Editora, 2012.

SAVIOLI, E. Batismo \& Salvação. Canal do YouTube Vai na Bíblia, 2017. Disponível em: <https://www.youtube.com/watch?v=7tR2yDse_E8>. Acesso em: 03/09/2021.

SCHMIDT, Flávio. Batismo apostólico x trinitariano. Canal do Evangelista Flávio, 2019. Disponível em: <https://www.youtube.com/watch?v=juwf8MsnjuU>. Acesso em: 07/09/2021.

SILVA, J. L. Teologia sistemática II: cristologia, antropologia e hamartiologia. Indaial, Santa Catarina: UNIASSELVI, 2009. Disponível em: $<$ https://www.uniasselvi.com.br/extranet/layout/request/trilha/materiais/livro/livro.php? codigo=25035 $>$. Acesso em: 16/08/2021.

SILVA, Rodrigo. O Batismo cristão. Canal do YouTube Evidências, 2014. Disponível em: https://www.youtube.com/watch?v=xdX4l8yMixY. Acesso em: 13/09/2021.

TÉRCIO, Paulo. A importância do batismo nas águas. Canal do YouTube NDV Brasil, 2017. Disponível em: https://www.youtube.com/watch?v=3gs1CEJUz6k\&t=1s. Acesso em: 23/08/2021.

TRIGO, Thiago. Conectivos lógicos. Site InfoEscola, s/d. Disponível em: <https://www.infoescola.com/matematica/conectivos-logicos/>. Acesso em: 23/09/2021.

VIEIRA, J.G.S. Metodologia da pesquisa científica na prática. Curitiba, Brasil: Fael, 2010. 
XAVIER, W. L. V. Uma vez salvo, salvo para sempre? Site Monergismo.com, [s.d.]. Disponível em: <http://www.monergismo.com/textos/perseveranca/uma-vezsempre-salvo_Wendell-Lessa.pdf>. Acesso em: 17/08/2021.

Enviado: Setembro, 2021.

Aprovado: Dezembro, 2021. 